\title{
Archipel
}

ARCHIPEL Études interdisciplinaires sur le monde insulindien

$102 \mid 2021$

Varia

\section{Creating and Mobilizing "Syonan" Youth: Youth and the Japanese Occupation of Singapore,}

\section{2-1945}

Créer et mobiliser la jeunesse "Syonan" : la jeunesse et l'occupation japonaise de Singapour, 1942-1945

\section{Edgar Bolun Liao}

\section{OpenEdition \\ Journals}

\section{Édition électronique}

URL : https://journals.openedition.org/archipel/2620

DOI : 10.4000/archipel.2620

ISSN : 2104-3655

\section{Éditeur}

Association Archipel

\section{Édition imprimée}

Date de publication : 31 December 2021

Pagination : 65-97

ISBN : 978-2-910513-87-0

ISSN : 0044-8613

\section{Référence électronique}

Edgar Bolun Liao, "Creating and Mobilizing "Syonan" Youth: Youth and the Japanese Occupation of Singapore, 1942-1945 », Archipel [En ligne], 102 | 2021, mis en ligne le 15 décembre 2021, consulté le 15 décembre 2021. URL : http://journals.openedition.org/archipel/2620; DOI : https://doi.org/

10.4000/archipel.2620 
EDGAR BOLUN LIAO *

\section{Creating and Mobilizing "Syonan" Youth: Youth and the Japanese Occupation of Singapore, 1942-1945}

The history of modern Singapore began on 30 January 1819 when British East India Company official Thomas Stamford Raffles signed a treaty with a local Malay noble to establish a trading settlement on the island. Within five years, Singapore grew into a bustling entrepot with a population of more than ten thousand. Its rapid growth was due to a combination of reasons - its free port status, its strategic position in the Straits of Malacca at the crossroads between trading networks and maritime traffic between Europe, the Arab World, India, Southeast Asia and China, and global developments such as the advancement in steamship and communications technologies and the opening of the Suez Canal in 1869. Singapore attracted large amounts of British investment and Chinese immigration and became the headquarters of British colonial influence in Southeast Asia, which included Britain's other interests in the Malay states in the Malay Peninsula and the island of Borneo. ${ }^{1}$ When the British announced the construction of a naval base in Singapore in 1923 (completed in 1938), this only added more lustre to the island-city's position as the heart of the British Empire in the region.

The ambitions of another imperial power dramatically interrupted British rule in Singapore in 1942. On 8 December 1941, the Japanese $25^{\text {th }}$ Imperial

* Sessional Lecturer, Department of History, University of British Columbia.

1. Wong Lin Ken, "Commercial Growth Before the Second World War," in A History of Singapore, eds. Ernest C.T. Chew and Edwin Lee (Oxford: Oxford University Press 1991), 42 . 
Army under the command of Lieutenant-General Yamashita Tomoyuki invaded British Malaya. ${ }^{2}$ They used landing and staging areas in northeastern Malaya and southern Thailand to launch swift incursions southwards. Starved of air and naval cover and reinforcements from Britain, itself beleaguered in Europe, British defences crumbled. On February 15, 1942, the besieged British forces surrendered in what British Prime Minister Winston Churchill termed "Britain's Worst Defeat." ${ }^{\text {"3 }}$ For the next three years and eight months, the Japanese imperial army made Singapore the capital of the Nampo (the "Southern Regions") of Japan's own pan-Asian empire, known as the Greater East Asia Co-Prosperity Sphere or the Dai Toa Kyoeiken. This pan-Asian empire comprised Japan's territorial gains in Korea, Taiwan, Manchuria and northern China, Malaya (renamed "Malai"), Singapore, Burma, Thailand, Indochina, the Philippines and Indonesia. ${ }^{4}$ Singapore itself was renamed Syonan-to ("Light of the South") and designated the Syonan Special Municipality (Syonan Tokubetu-si) to begin the colony's transformation into a Japanese imperial city. ${ }^{5}$ Singapore became, in Gregg and Gillian Huff's words, a "nerve centre for Japanese military operations" in Southeast Asia. The island-city possessed a natural harbour and four airports, advanced port, military, industrial, and naval facilities, and telegraph links to all large cities and some towns in Southeast Asia. ${ }^{6}$ The one vital resource the new Japanese masters of the island-city lacked was a loyal and industrious population to serve as imperial subjects and docile labour.

2. Paul Kratoska, The Japanese Occupation of Malaya and Singapore, 1941-45: A Social and Economic History, $2^{\text {nd }}$ edition (Singapore: NUS Press, 2018), 3. The origins of the invasion laid in the rise of tensions between Western powers and Japan in the 1930s. The British, Dutch, and US colonial administrations restricted exports of vital oil and metals from their Southeast Asian colonies to Japan and limited the import of Japanese goods. The economic pressures on Japan allowed right-wing ultra-nationalistic military officers, intellectuals, and politicians to pursue a military build-up.

3. There is a substantial amount of literature devoted to explaining the British's quick defeat. The explanations range from incompetent leadership from, and in-fighting among, the military commanders, to larger strategic explanations such as the German advances in Europe and Japan's raid on Pearl Harbor, which hindered the arrival of British or American reinforcements. See Brian Farrell's The Defense and Fall of Singapore (Stroud: Tempus, c2005) for a magisterial account.

4. Eunice Thio, "The Syonan Years, 1942-1945," in A History of Singapore, eds. Ernest C.T. Chew and Edwin Lee (Singapore: Oxford University Press 1991), 95.

5. Vivian Blaxell, "New Syonan and Asianism in Japanese-era Singapore," The AsiaPacific Journal, Jan 1, 2008, Vol. 6 Issue 1. Accessed at https://apjjf.org/-VivianBlaxell/2644/article.html.

6. Gregg Huff and Gillian Huff, "The Second World War Japanese Occupation of Singapore," Journal of Southeast Asian Studies 51, 1-2 (2020), 256. 
Present-day Singaporean state-authored histories and commemorations valorized the Japanese occupation as a traumatic moment in Singapore history that awoken Singaporeans to the importance of self-reliance and perpetual vigilance against foreign aggressors. As Kevin Blackburn and Karl Hack noted in their book on the period's remembrance in Singapore and Malaysia, the Singapore state has configured the collective memory of the period into a "single unifying myth of all races suffering together" for the purposes of stimulating national consciousness among Singaporeans. ${ }^{\text {? }}$

Academic scholarship on the Occupation has been more nuanced. The bulk of this scholarship focused on the military aspects of the British forces' capitulation. In the 1990s, Singapore-based historian Paul Kratoska and Japanese scholar Yoji Akashi led a group of researchers to produce seminal studies of the Occupation's social and economic aspects. Akashi, in particular, has used the Syonan Shinbum, oral testimonies, memoirs, and previously un-utilized Japanese-language sources to study Japan's cultural and social policies in substantial depth and detail. ${ }^{8}$ Most recently, Gregg Huff and Gillian Huff built on this existing scholarship to produce even more comprehensive and illuminating studies of Japanese Occupation's economic and social impact on Southeast Asia. ${ }^{9}$ Gregg Huff and Shinobu Majima also translated and compiled another important volume of research studies by Japanese academics and civil servants during the war. These empirically-rich reports were important sources, as Huff notes, as most Japanese-language records of wartime Syonan were destroyed near the end or just after the war. ${ }^{10}$

Within the above-mentioned existing studies, the Japanese administrators' efforts to mobilize and discipline children and youth are usually submerged within the broader examination of Japanese social policies. Recently, a Japanese scholar Masakazu Matsuoka has produced interesting new research using magazines and cartoons produced for children and youth in Singapore to show how Japanese musicians, artists, and intellectuals participated in

7. See Kevin Blackburn and Karl Hack, War Memory and the Making of Modern Malaysia and Singapore (Singapore: NUS Press, 2012), 336.

8. Yoji Akashi, "Japanese Cultural Policy in Malaya and Singapore, 1942-1945," in Japanese Cultural Policies in Southeast Asia during World War 2, ed. Grant K. Goodman (New York: St. Martin's Press, 1991). See also Yoji Akashi, “Colonel Watanabe Wataru: The Architect of the Malayan Military Administration, December 1941 - March 1943," in New Perspectives on the Japanese Occupation in Malaya and Singapore, 1941-1945, eds. Yoji Akashi and Yoshimura Mako (Singapore: National University of Singapore Press, 2008), 33-64.

9. Gregg Huff, World War II and Southeast Asia: Economy and Society under Japanese occupation (Cambridge, UK; New York, NY: Cambridge University Press 2020).

10. Gregg Huff and Shinobu Majima (eds), World War II Singapore: The Chōsabu Reports on Syonan (Singapore: NUS Press, National University of Singapore, 2018), 5. 
the enterprise to "Nipponize" local children and youth. ${ }^{11}$ From these extant works, we know that the cultural politics of youth in Singapore did not begin with the returning British colonial administration, or the subsequent Labour Front and People's Action Party governments. This article examines these different efforts of Japanese military officers and civil administrators to school and mobilize youth in Singapore during this period. It argues that these Japanese imperialists, animated by the fantasy of moulding ideal new subjects for an envisioned new Japanese imperial city, created associations between the disciplining of the young and the creation of a new society and polity in Singapore, one that looked towards Japan as regional hegemon. These military and civilian administrators needed to address the problems of dislocated and rebellious youth in the territories they occupied. They also saw the young as the answer to the challenges of acquiring local manpower, support, and legitimacy for Japan's empire. These needs and interests fuelled their efforts to create new subjects out of Singapore's children and youth and to discipline their bodies for incorporation into a new pan-Asian Japanese empire. Even though these attempts failed, they paved the way for the subsequent social policies and disciplinary projects of the British colonial and local nationalist governments after the end of the war.

So doing, this article brings modern Singapore history into productive conversation with the emerging history of childhood and youth and building on the work already done by David Pomfret, Christina Jialin Wu, and Rachel Leow. ${ }^{12}$ The article shows that the Japanese Occupation was impactful for

11. Masakazu Matsuoka, “'Shonantou' ni okeru 'bunkajin': Kodomo muke shinbun kara no kousatsu ('Intellectuals' in Singapore under Japanese Occupation: A Consideration of Their Involvement in a Newspaper for School Children)," Annual Review of Historical Studies of Colonial Education 14 (2012): 141-159; Masakazu Matsuoka, "Nihon senryou ka singaporu ni okeru kodomo muke puropaganda no shishou teki kigen: Doushinshugi to nanpou muke nihongo kyoiku no renzokusei ni kansuru kousatsu (Comprehensive Study on the School Textbooks and New Education Movement in Japanese Colonies and Japanese-Occupied Areas)," Research Report of the JSPS Grant-in-Aid for Scientific Research (B) 22330207 (2010-2012)," March 2013: 297-309; Masakazu Matsuoka, "Nihon gunsei ka Singaporu ni okeru kodomo muke ongaku kousaku (Japanese Propaganda through Music toward School Children during Japanese Occupation of Singapore)," Researches of Educational History in Asia 18 (March 2009): 48-64. My gratitude to Tomoharu Hirota for his assistance in translating these articles for my comprehension.

12. Christina Wu Jialin, "A Malayan Girlhood on Parade: Colonial Femininities, Transnational Mobilities and the Girl Guide Movement in British Malaya," in Transnational Histories of Youth in the Twentieth Century, eds. Richard Ivan Jobs and David Martin Pomfret (London: Palgrave Macmillan 2015); Christina Wu Jialin, "A Life of Make-Believe: Being Boy Scouts and 'Playing Indian' in British Malaya (1910-1942)," Gender \& History 26, no. 3 (November 2014), 589-619; Rachel Leow, "Age as a Category of Gender Analysis: Servant Girls, Modern Girls, and Gender in Southeast Asia," The Journal of Asian Studies 71, no. 4 (2014), 975-990; David M. 
Singapore's post-1945 nation-building and state-building in a less-acknowledged way - it heralded the intersection of state-society relations and age relations in Singapore. Japanese policies and propaganda paved the way for the greater consciousness of youth by naturalizing the socialization and mobilization of youth as a domain of state concern, and by normalizing the fulfillment of young people's aspirations as a source of political legitimacy. In addition, the lens of age relations allows us to go beyond the narrow national frame with which the Singapore government and Singapore's national histories has construed the Japanese Occupation. Instead, the article connects Japanese efforts to socialize, mobilize, and police children and youth in Singapore to a longer history of youth in the new imperial metropole of Japan dating from the end of the $19^{\text {th }}$-century. ${ }^{13}$ A Japanese Youth Corps, the equivalent of the British Boys' Scouts, was established in Singapore in March 1925 with an inaugural group of thirty-one members, to which a Junior troop with 90 members was added in August 1933. More research, which may be hindered by scarcity of sources, is warranted for the pre-war activities of Japanese youths and youth movements in Singapore. That the Japanese Scouts reportedly held "a last camp" in February 1940, sometime before the actual Japanese invasion of Malaya, suggest that the increasing tensions between the British authorities and Japan affected the ability or freedom of Japanese youth movements to function in Singapore. ${ }^{14}$ There does not appear to be a direct connection between the existence of Japanese youth movements and the Japanese military authorities' programs for the socialization and mobilization of youth during the Occupation period. Nonetheless, the Japanese Youth Corps' existence was another signpost of the Japanese state's strong beliefs about disciplining and mobilizing of youth for its modernization programs and imperial enterprises, as the above-mentioned seminal works by Ambaras, Chatani, and Frühstück have shown. Singapore thus presents an exceptional case where the history of the making of youth was connected to not one, but two different imperial metropoles.

Pomfret, "Child Slavery' in French and British Far-Eastern Colonies, 1880-1945," Past and Present 201, no. 1 (2008): 175-213; David M. Pomfret, "Raising Eurasia': Race, Class and Age in Hong Kong and Indochina," Comparative Studies in Society and History 51, no. 2 (2009): 314-343.

13. David R. Ambaras, Bad Youth: Juvenile Delinquency and the Politics of Everyday Life in Modern Japan (Berkeley: University of California Press, 2006); Sabine Frühstück, Playing War: Children and the Paradoxes of Modern Militarism in Japan (Oakland, California: University of California Press, 2017); Sayaka Chatani, Nationempire: Ideology and Rural Youth Mobilization in Japan and Its Colonies (Ithaca: Cornell University Press, 2018).

14. Shingaporu Nihonjinkai (The Japanese Association, Singapore), 戦前シンガポー ルの日本人社会 : 写真と記錄 (Prewar Japanese community in Singapore: Picture and Record), (Singapore: Shingaporu Nihonjinkai, 1998), 156-158, 230-232. 


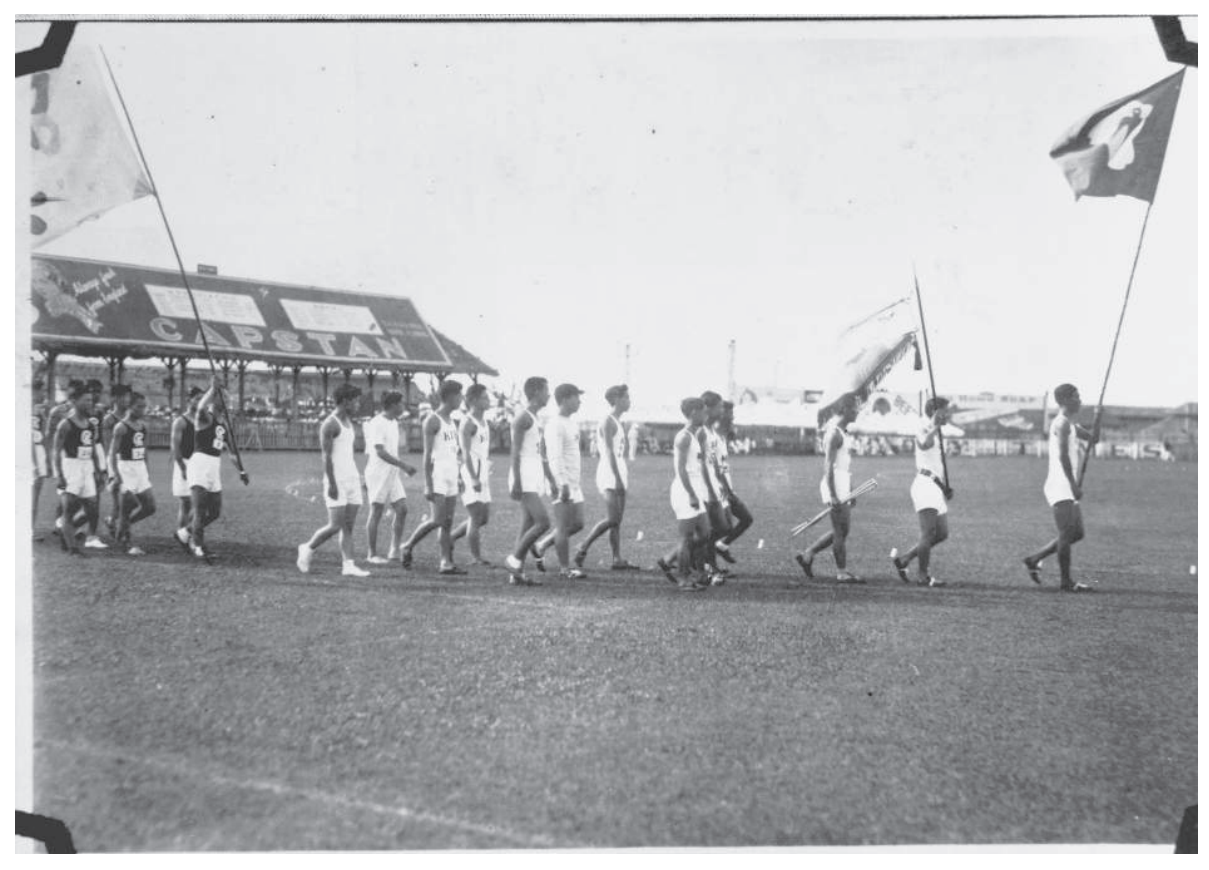

Fig. 1- "The Tsubame Team (volunteers of the Japanese Youth Club) marching at the stadium", c. 1930s image no. 19990002629 - 0092, negative no. T2000,0429, photo accession no. 178690, with permission of National Archives of Singapore.

The paper uses the Syonan Shimbun, the English-language newspaper in Singapore that the Japanese Military Administration (JMA) turned into its principal propaganda vehicle, to discuss how the bodies and minds of children and youth became sites of Japanese attempts to inscribe a new modernity under Japanese hegemony. As a propaganda broadsheet, the Syonan Shimbun is a problematic source to reconstruct and examine Japanese social and cultural policies. Yet, its purpose also means that the newspaper is useful to illuminate the images of ideal youth and children that the Japanese military officers and civilian administrators tried to construct and promote, as well as the significances and meanings they endowed upon successfully socialized and mobilized Syonan children and youth. The newspaper also allows us to examine how Japanese officials attempted to instrumentalize and mobilize the bodies of the young in gendered ways. On the one hand, Japanese military officers and civilian administrators valorized young male bodies as valuable labourers and auxiliary combatants. On the other hand, they deployed female bodies in subordinated roles as symbols of progress under Japanese dominance or as replacement for male youth in roles deemed auxiliary or secondary to the wartime economy and war effort. Though there were other pre-war Japaneselanguage newspapers, and other language-editions of the Syonan Shimbun, 
these have not been consulted for this study due to my lack of accessibility. ${ }^{15}$ At the same time, the fact that the Japanese Propaganda Department exercised close supervision over all media content suggests that these publications would closely reflect the same information about Japanese policies towards children and youth during the Occupation era.

\section{An Imperialist Administrator}

One of the earliest researchers to study Japanese social policies in Singapore during the occupation was a $\mathrm{PhD}$. candidate from the University of British Columbia's Department of History. Between 1972 and 1973, Harold E. Wilson, carried out research for his dissertation in Singapore. This became an early classic of Singapore's educational history: Social Engineering in Singapore. ${ }^{16}$ In this comprehensive study of educational policies between 1819 and 1972, Wilson incorporated interviews with witnesses of the occupation. Among his interviewees was a Japanese individual, Mamoru Shinozaki.

Shinozaki was no ordinary eyewitness. He was working in Singapore as a press attaché of the Consulate-General of Japan when the British imprisoned him for suspected espionage just before the Japanese invasion of Malaya in December 1941. By then, there were already a sizable Japanese community on the island. According to the Japanese Association of Singapore, the community grew from fewer than 1,000 before 1900, to about 3,200 in $1930 .{ }^{17}$ After the Japanese army freed him, Shinozaki became the principal advisor to the Japanese Military Administration (JMA) in Singapore, its Chief Education Officer, and subsequently its $\mathrm{Ko}$-sei Cho (head of the Welfare Department). Hence, he was the key civilian official in charge of education, welfare, and other social policies. When he was placed on trial for war crimes after the Japanese surrender in August 1945, local community leaders, like Chinese businessman

15. See an undergraduate graduating thesis for a survey of pre-war Japanese newspapers, Ophelia Ooi, "Inquiry into the Political Activities of the Japanese in Singapore, 1930-1942," unpublished academic exercise, Department of History, University of Singapore, 1980, 15-23. During the Japanese Occupation, the Japanese Propaganda Department also supervised the publication of a Japanese edition of the Syonan Times, a Chinese edition (the Cheow Nam Jit Pao or Syonan Daily), and a Malay version (Berita Malai or Malaya News).

16. Harold E. Wilson, Social Engineering in Singapore: Educational Policies and Social Change, 1819-1972 (Singapore: Singapore University Press, 1978). He also produced a working paper on education policies under the Japanese administration. Harold E. Wilson, "Educational Policy and Performance in Singapore, 1942-1945," ISEAS Occasional Paper No. 16 (Singapore: Institute for Southeast Asian Studies, 1973).

17. Shingaporu Nihonjinkai (The Japanese Association, Singapore), 戦前シンガポール の日本人社会：写真と記錄 (Prewar Japanese community in Singapore: Picture and Record), 1; Shingaporu Nihonjinkai (The Japanese Association, Singapore), シンガポ 一ル日本人社会百年史：星月夜の耀 (100 Year History Of Japanese Community In Singapore (1915 2015)), (Singapore: Shingaporu Nihonjinkai, 2016), 5. 
and philanthropist Yap Pheng Geck, intervened and vouched for Shinozaki as someone to whom they were indebted for shielding them from the full brunt of Japanese persecution. ${ }^{18}$ Historians of the occupation have used Shinozaki's memoirs to study Japanese actions. These included the infamous Sook Ching massacre in February 1942. Three days after Singapore's surrender, Japanese military officers ordered all Chinese males between the ages of eighteen and fifty to report to various checkpoints for inspection and registration. There, they singled out those suspected of being anti-Japanese elements and ferried them to areas in the east of Singapore for execution. Historian Constance M. Turnbull, who wrote the standard textbook of modern Singapore history still in use today, estimated that these Sook Ching (Chinese for "Purification") massacres killed about close to 25,000 Chinese. ${ }^{19}$

While Singapore's community leaders then hailed Shinozaki as a hero, Vivian Blaxell reminds us in a recent essay that Shinozaki was very much an "imperial bureaucrat" driven by the fundamental beliefs that inspired Japanese imperialism in Asia. ${ }^{20}$ Even if he disagreed with his more belligerent military colleagues' harsh methods, Shinozaki did not question "the "rightness" of Japanese imperialism. A thorough examination of the Syonan Shimbun shows that Shinozaki was clearly a committed imperialist involved in Japan's efforts to produce new ideal subjects in Singapore out of its children and youth. That Japanese military and civilian administrators endeavoured to socialize and mobilize the young in Singapore was no surprise. As Sabine Frühstück has shown, by the 1930s and early 1940s, Japan's imperialist government "came to tightly embrace children." They sought to transform Japanese children and youth "into little (militarized) adults (shokumin)" and mobilize them as labour and as combatants to support the Japanese war effort. ${ }^{21}$ Chatani's recent study dates the Japanese state's attempts at mobilizing youth in Japan and in its colonies of Taiwan and Korea even earlier, to the turn of the $20^{\text {th }}$ century. ${ }^{22}$ These efforts to mobilize and militarize children and youth had parallels throughout Japan's short-lived empire in Asia during the Second World War. For instance, Japanese officers and administrators set up youth organizations and paramilitary units in many occupied territories for the purpose of training

18. Mamoru Shinozaki's memoirs, Syonan - My Story: The Japanese Occupation of Singapore (Singapore: Asia Pacific Press, 1975), included a testimony from Yap Pheng Geck and a foreword by Wilson.

19. C.M. Turnbull, A History of Modern Singapore, 1819-2005 (Singapore: NUS Press, 2009), 197.

20. Blaxell, "New Syonan and Asianism in Japanese-era Singapore."

21. Frühstück, Playing War: Children and the Paradoxes of Modern Militarism in Japan, 7.

22. Chatani, Nation-empire: Ideology and Rural Youth Mobilization in Japan and Its Colonies. 
local youth. Joyce Lebra has contributed pioneering research on this. ${ }^{23}$ Well-known examples of these nationalist youth movements and military organizations include the Indian National Army, Burmese Independence Army, PETA ("Tentara Sukarela Pembela Tanah Air," or the "Volonteer Army of Defenders of the Homeland") in Indonesia, and the Kesatuan Melayu Muda (The "Young Malays Union") in Malaya. Therefore, Japanese imperialism in Southeast Asia was an integral part of the history of youth mobilization in Southeast Asia. This was notwithstanding the well-known stories of the Japanese's cultivation of young nationalists, for instance the Thakins (mostly students of Rangoon University and young labour organizers) in Burma, to collaborate with Japan against the British. ${ }^{24}$

In Singapore, the hardline policies of the commander of the Gunsei-bu (Military Administration), Colonel Watanabe Wataru, characterized the early JMA administration period between February 1942 and March 1943. Watanabe believed that the local communities had learnt a "hedonistic and wasteful way of life" from the British and had to "account for their past mistakes" and be subjected to "spiritual cleansing" before they could return to their everyday lives. ${ }^{25} \mathrm{He}$ forced Chinese community leaders to contribute of 50 million yen towards Japan's war efforts, closed Chinese schools, and prohibited of the use of the Chinese language in schools.

Wataru also believed in "Nipponizing" the local population. This meant acculturating them in the Japanese language and culture and instilling in them beliefs about Japan's cultural and moral superiority. Before he became Syonanto's chief administrator, Wataru authored two Japanese Total War Institute studies on cultural and educational policies in Japan's occupied territories. He also sent out a memorandum "Principles for Reforming School Education" to governors of Japanese-occupied areas on 6 October 1942. In these writings, he argued for the vigorous implementation of "Nipponization" programs. He emphasized that the core curriculum used in local schools "ought to be centered on the Emperor system with the understanding that the indigenous people of Malaya were to be citizens of Imperial Japan in the future." ${ }^{26} \mathrm{He}$ made no pretence, therefore, that the Japanese military was preparing the local

23. Joyce C. Lebra, Japanese-Trained Armies in Southeast Asia: Independence and Volunteer Forces in World War II (New York: Columbia University Press, 1977).

24. Christopher Bayly and Tim Harper, Forgotten Armies: Britain's Asian Empire and the War with Japan (London: Penguin Books, 2005), 9.

25. Yoji Akashi, "Colonel Watanabe Wataru: The Architect of the Malayan Military Administration, December 1941- March 1943," 34.

26. Yoji Akashi, "Japanese Cultural Policy in Malaya and Singapore, 1942-1945," in Japanese Cultural Policies in Southeast Asia during World War 2, ed. Grant K. Goodman (New York: St. Martin's Press, 1991), 120. 
population for independence. Instead, the people of Malaya were to be guided into a new Asiatic modernity under Japanese overlordship.

Though Japan fought under the banner of liberating Southeast Asia from Western colonialism, its imperialist government and expansionist-minded military coveted the rich natural resources in the regions. Vivian Blaxell has written an excellent article summarizing the complex set of ideas that animated Japanese imperialism. ${ }^{27}$ These ideas are explored more comprehensively in the work of Eri Hotta, and more recently, Jeremy Yellen. ${ }^{28}$ The Japanese "Dai Toa" ideology promoted a vision of a Great East New Order led and dominated by Japan, where Asian peoples progressed and prospered under Japanese tutelage. The Asian countries Japan liberated would enjoy autonomy but remain dependent on Japan's hegemony - a patently paradoxical fantasy. ${ }^{29}$ Japanese politicians, intellectuals, and military officers invoked the concept of Hakkoichiu ("Eight Corners of the World Under One Roof" or "the rule of all peoples under one sovereign") to encapsulate this vision. They advanced the idea of Nihonshugi ("Japanism"), a brand of Japanese exceptionalism that emphasized "the uniqueness and superiority of Japan's social, political and cultural heritage" and the ideals of self-sacrifice and loyalty to the family and the state..$^{30}$ These ideologies undergirded Japanese practices and methods in molding new imperial subjects in the territories they occupied. The minds and bodies of children and youth were the site where the Japanese tried to imprint these ideologies. As Blaxell points out, "Japanese brutality coexisted with a different operation of power, one that aimed to be constructive rather than destructive in the effort to constitute the Japanese Empire." 31

In Singapore, the Syonan Times (later renamed the Syonan Shimbun) became the main media platform to promote the ideals of Hakko Ichiu and Dai Toaism. ${ }^{32}$ In the early months of the Occupation, the JMA made a futile attempt

27. Blaxell, "New Syonan and Asianism in Japanese-era Singapore."

28. See Eri Hotta, Pan-Asianism and Japan's War, 1931-1945 (New York: Palgrave Macmillan, 2007); Jeremy Yellen, The Greater East Asia Co-Prosperity Sphere: When Total Empire Met Total War (U.S.A.: Cornell University Press, 2019).

29. Turnbull, A History of Modern Singapore, 199.

30. Ivan Morris, ed., Japan 1931-1945: Militarism, Fascism, Japanism? (Lexington: D.C. Heath and Company, 1963), xi-xii.

31. Blaxell, "New Syonan and Asianism in Japanese-era Singapore."

32. When the Japanese military forces conquered Singapore, they took over all existing newspapers and media companies. The most popular English-language newspaper, The Straits Times, which is still the main English-language newspaper today, was renamed the Shonan Times on 20 February 1942. The name was changed to the Syonan Times the following day. The newspaper became the Syonan Shinbun on 8 December 1942, and then the Syonan Shimbun on 8 December 1943. The Japanese used the Japanese calendar based on the reign name of Emperor Hirohito. Hence, the Japanese used these dates 2602 (Syowa 16) to 2605 (Syowa 20) to refer to the years of the Japanese Occupation 
to reach out to a younger audience through the newspaper. Its very first issue featured a new section known as "the Children's Corner," where the fictional 'Uncle Ahnah' wrote letters to "his dear Nephews and Nieces." 33 Over the next few issues, 'Uncle Ahnah' disseminated knowledge about the Japanese language and Japan's geography and history to children and exhorted local children to play their part in establishing a New Order in Asia. ${ }^{34}$ They "must work for the common good, or in other words, for the benefit of all," even as the Japanese were now "masters of this island." 35 The column existed only for a short period of time. 'Uncle Ahnah"s very last letter on 2 May 1942 gave a clue as to why the column ceased - he wrote that "one nephew complained that my letter written to you on April 1, 2602, was too difficult for children in the lower classes. Therefore today I shall tell you a little story in a simple way." ${ }^{\text {"36 }}$

The admission that the intended audience found the information inaccessible and uninteresting was an early sign that Japanese propaganda efforts were based on ambitious wishful thinking. Nevertheless, the Syonan Shinbum continued to feature propaganda, such as illustrations of student learning and school activities in Japan, to extol the strengths of the Japanese educational system. On occasion, the newspaper featured accounts of local children from the different ethnic communities learning Japanese enthusiastically. Six-yearold Eurasian Maureen Aeria told her mother that she wanted to go to school and learn about Japan like other children. Eleven-year-old Arab schoolboy Syed Mohamed bin Abu-bakar bin Yahya declared that "Nippon has not only freed us from the bondage of the white people, but has taught us to be clever, diligent and self-respecting." ${ }^{37}$ Given the newspaper's nature as a propaganda broadsheet, it is unlikely that these children were sincere in their adulation, or that they even existed at all. We can infer, nonetheless, that the JMA and their propagandists were keen to demonstrate strong support for Japanese learning among children of all ethnic communities. This desire is especially evident in how the JMA and Shinozaki mobilized school children to participate in public rallies or commemorations. Frühstück observed that Japanese propaganda frequently urged Japanese children, as well as colonized and enemy children, to be grateful to the "protectors of Japan" - Japanese soldiers. These propaganda efforts often portrayed the Japanese Imperial Army soldier as "an object of affection by children on both sides." 38 Indeed,

between 1942 and 1945. The newspaper issues were dated accordingly.

33. "The Children's Corner," The Syonan Times, April 1, Koki 2602 Syowa 17 (1942), 3.

34. “The Children's Corner," The Syonan Times, April 25, Koki 2602 Syowa 17 (1942), II.

35. "The Children's Corner," The Syonan Times, April 1, Koki 2602 Syowa 17 (1942), 3.

36. The Syonan Shimbun Saturday Supplement May 2, Koki 2602 Syowa 17 (1942), III.

37. The Syonan Shimbun, February 18, Koki 2604 Showa 19 (1944), 2.

38. Frühstück, Playing War, 127. 
the Syonan Shimbun occasionally published depictions of Japanese soldiers and local children demonstrating affection for each other.

The mobilization of local children and youth to pay homage to symbols of the Japanese state also became a frequent practice. For instance, on the morning of 8 December 1942, Shinozaki led a parade of youth from the major communities to a Japanese war shrine in the central area of Bukit Timah to celebrate the anniversary of Japan's invasion of Southeast Asia. ${ }^{39}$ Such displays were also meant to exhibit spectacles showing local children and youth's support for the Japanese military - the engine of Japan's imperial ambitions. Eight months earlier, children and youth took center-stage within the commemoration of the Japanese Emperor's birthday on 29 April 1942. Shinozaki's Education Department organized a march comprising thousands of local schoolchildren. ${ }^{40}$ The parade of children, carrying flags and singing a Japanese patriotic song, Aikoku Koshin, joined hordes of assembled locals gathered at the Padang, a prominent field in front of the Singapore City Hall. Together, the assembly of adults, children and youth bowed in the direction of the Imperial Palace, shouted Banzai! (Long Live the Emperor!) three times and sang the Kimigayo (Japan's National Anthem) ${ }^{41}$ According to Shinozaki, the spectacle moved General Yamashita, the commander of the $25^{\text {th }}$ Imperial Army, to tears. The Tiger of Malaya, as Yamashita was dubbed for his leadership in the swift conquest of Malaya and Singapore, turned to Shinozaki and whispered, "Just like Japanese children, aren't they?"42 For Yamashita, the bodies of local children became emotive metonyms of the pan-Asian Japanese empire he envisioned.

Japanese military officers and civilian administrators agreed that education was a powerful institution to reproduce Japanese values and beliefs in local children and youth. Harold Wilson argued that the Japanese authorities tried to promote education in Singapore to "serve the twin purposes of cultural absorption and technical/industrial development." ${ }^{\text {"3 }}$ This was not unique to Singapore but part of Japanese policy empire wide. Modern Japanese education legislation, in Frühstück's words, "conceptualized children as yetto-be-formed individuals primarily designed to realize adult goals for the nation." "44 In March 1942, the Japanese government adopted an educational policy "to unite the cultures of the indigenous peoples of the southern region

39. The Syonan Shimbun, December 1, Koki 2602 Syowa 17 (1942), 4.

40. Turnbull, A History of Modern Singapore, 205.

41. Shinozaki, Syonan - My Story, 40. See also The Syonan Times, April 29, Koki 2602 Syowa 17 (1942), III.

42. Shinozaki, Syonan - My Story, 43.

43. Wilson, "Educational Policy and Performance in Singapore, 1942-1945," 2.

44. Frühstück, Playing War, 27. 
with Japanese culture under the spirit of Hakko Ichiu (universal brotherhood), to teach industrial technologies and the Japanese language as the lingua franca of the Co-Prosperity Sphere and to promote the spirit of labour." ${ }^{45}$ In the same month, the JMA started the "Nipponization" programs in Singapore. They gave Shinozaki the role of re-opening the schools in Syonan-to and transforming them into institutions to teach a Japanese-style curriculum to Singapore's children and youth. The JMA was the first to attempt to create an integrated educational system to produce new subjects with a common language and outlook, and common values and identities in Singapore - based on Japan as the cultural model and exemplar. Their efforts pre-date the subsequent policies of the British colonial and local nationalist governments. Beneath the rhetoric of cultural liberation and progress, Japanese cultural and educational policies were, as Yoji Akashi has emphasized, "paternalistic if not undisguisedly racist." ${ }^{46}$ The military officials, instructors, teachers and officials involved in propagandizing Japanese culture took it for granted that the local population they liberated from Western colonial yoke had not "developed their cultural sophistication to a level deemed worthy of independence and nationhood." Hence, they felt justified in subjecting their new subject peoples to a cultural and educational policy of kominka kyoiku (education for transforming citizens into the Emperor's subjects) based on learning the Japanese Imperial Way, the Japanese Emperor cult, the Japanese language, the Japanese culture, and the Japanese seishin (spirit). ${ }^{47}$ They wanted to replace the previous segregated landscape of English-medium schools and vernacular schools in Singapore with a system based on the Japanese model: common public schools that provided compulsory, universal primary schooling. ${ }^{48}$

The pedagogical programs and methods used in Singapore followed those used in Japan, where administrators emphasized physical education and character development to develop healthy, disciplined, loyal and vigorous children. ${ }^{49}$ Each morning, schoolchildren stood in the direction of Japan and sang the Japanese national anthem and other patriotic songs. Schools were required or encouraged to teach in Japanese, though for practical reasons, instruction was given in Malay and English until students could attain proficiency in Japanese. ${ }^{50}$ The curriculum included more physical activities

45. Akashi, "Colonel Watanabe Wataru: The Architect of the Malayan Military Administration," 48.

46. Aksahi, "Japanese Cultural Policy in Malaya and Singapore, 1942-1945," 148.

47. Ibid., 117-118.

48. Wilson, "Educational Policy and Performance in Singapore, 1942-1945," 28.

49. See Frühstück, Playing War, 28-30 for a succinct account of the impact of Japanese militarism on schools as educators tried to play their part in producing healthy, disciplined, physically fit Japanese children, especially boys, for the Japanese nation.

50. Turnbull, A History of Modern Singapore, 209. 
like mass drills and training in fencing, judo, and other martial arts, and moral education. Clearly, Nipponization meant more than learning the Japanese language and pledging loyalty to the Japanese Emperor and state. It also entailed the disciplining of the young in a new physical culture, moral purity, and patriotic conduct. The young body became an index of British debauchery and Japanese civilizational superiority, where Japanese officers and educators frequently juxtaposed the products of their educational program with the indolent, undisciplined bodies of local children and youth under British rule.

Beyond this idealistic rhetoric, the revival of the local education system was also meant to address the problem of restless youth on the streets by enclosing them in institutions where they could be trained into docile imperial subjects. Historians Christopher Bayly and Tim Harper noted that "the main target of Japanese policies of social engineering was youth." Japanese officers associated young people "roaming uncontrolled on the streets" with petty crimes and civil disorder and even with "the delinquent Western culture of the towns." ${ }^{1}$ Mamoru Shinozaki recounted that the JMA appointed him as Chief Education Officer - even though he had no experience or training in education - and asked him to re-open schools quickly so as to get the large number of youths "off the streets and under control." 52 In his next appointment as head of the Welfare Department, Shinozaki was also tasked "to reduce and eventually eliminate the large number of boy vagrants and idle youths who have infested the streets of the city since the fall of Singapore." ${ }^{53}$ One measure was the re-opening of the Boys' Reformatory to occupy the time of about two hundred boys by training them in tailoring, carpentering, and Japanese. The Salvation Army's Boys' Home was converted into the Syonan Home to provide a refuge and reforming institution for fifty-two wayward or orphaned youths between the ages of eight to sixteen. ${ }^{54}$ The Home's small capacity meant that its impact was negligible in the face of the large numbers of displaced youth in the island-city. Nevertheless, Japanese propagandists exploited its existence to underline how Japanese disciplining methods helped to convert these boys "to a correct way of life...through clean and wholesome living." 55 The Welfare Department also reopened the Poh Leung Kok (an agency set up by the colonial government to protect girls and women from prostitution or involuntary servitude) and the various orphanages and institutions for the poor managed by the Roman Catholic Church. The urgent need to provide social welfare for children and youth thus posed another set of

51. Christopher Bayly and Tim Harper. Forgotten Armies, 228.

52. Wilson's interview with Shinozaki on 4 November 1972, cited in Wilson "Educational Policy and Performance in Singapore," 5.

53. The Syonan Times, November 28, Koki 2603 Syowa 18 (1943), 4.

54. The Syonan Times, September 27, Koki 2602 Syowa 17 (1942), 4.

55. The Syonan Times, September 27, Koki 2602 Syowa 17 (1942), 4. 
difficulties for the JMA's disciplinary fantasies - before they could even produce ideal Japanese citizens, they had to first address the socio-economic impact of wartime dislocation and devastation on the young.

Japanese efforts to Nippon-ize local youth also extended to sending selected students from its occupied territories to Tokyo to study so as "to assist in the establishment of the New Order in East Asia based on new Asiatic ideals, under the leadership of Nippon." ${ }^{" 6}$ Beyond the increased provision of mass education modelled along Japanese lines, Colonel Watanabe Wataru wanted to train selected local male youth to become leaders. ${ }^{57} \mathrm{He}$ established the Syonan Koa Kunrenjo (Asia Development Training Institute) on 15 May 1942 to train selected young men between seventeen and twenty-five years old to become leaders "for the construction of a new born Malaya." 58 These trainees underwent rigorous physical and spiritual training, along with Japanese language study, for three months; the curriculum was modelled after the Japanese military system. The Syonan Koa Kunrenjo trained about 1,000 graduates in Singapore and Malaya before its closure in July 1943, many of whom, according to Yoji Akashi, became prominent people in post-war Malaya. ${ }^{59}$ Outstanding trainee graduates were also given the opportunity to study in Japan through "the Southern Special Students (Nanpo Tokubetsu Ryugakusei)" program. The objective, unsurprisingly, was to produce a future leadership friendly to the Japanese. ${ }^{60}$

Beyond these embryonic efforts to nurture pro-Japan youth leaders, the JMA tried to enlist local male youth in paramilitary organizations to support their regular military forces. This was especially after the Japanese forces began to buckle under the Allied armies' counterattack from mid-1942. With this turning of the tide of war, the JMA urgently mobilized local manpower for its labourstarved military facilities and for its local defence needs. In early 1943, they began recruiting Heiho or "auxiliary servicemen" in Malaya, Singapore, and Burma. These were non-combatants who joined the army's auxiliary services, wore uniforms, lived beside Japanese forces, and performed light work and manual labour. ${ }^{61}$ This policy was touted as another solution to the problem of youth unemployment and delinquency. In December that year, units of Giyugun (Volunteer Army) and Giyu-tai (Volunteer Corps) were formed in the various regions under Japanese military control. The Giyu-Gun was a military force consisting of approximately 2,000 young men armed with machine guns

56. The Syonan Sinbun, January 19, Koki 2603, Syowa 18 (1943), 1.

57. Akashi, "Colonel Watanabe Wataru," 48.

58. The Syonan Times, May 22, Koki 2062 Syowa 17 (1942), 4.

59. Akashi, "Colonel Watanabe Wataru," 49.

60. Kratoska, The Japanese Occupation of Malaya and Singapore, 61.

61. Ibid., 86 . 
and rifles. Its purpose was to defend the coastline and help preserve public peace and order ${ }^{62}$ In particular, the Japanese authorities sought to recruit "male youths between the ages of 16 to (sic) 30, who [were] brave and strong of physique." ${ }^{163}$ The Giyu-Tai was a volunteer troop of semi-soldiers and semi-farmers organized into small units to man local defence posts, serve as air raid wardens or police post sentries, and help maintain peace and order. ${ }^{64}$ There is already substantial discussion of these three units in the above-mentioned existing literature and there is no need to dwell on their activities.

Nonetheless, it is important to observe that these Japanese efforts to mobilize local youth to serve in these units increased consciousness of male youth as agents. The Syonan Shinbum regularly exhorted local youth, especially Malay youth, to join these organizations, valorizing service in these units as the "Duty of Youth of [the] Country." Malay officers attached in the Giyu-gun, added their own exhortations, invoking association between military training and service with nationalism and citizenship, - training in the Giyu-gun would make the enlistees "new youths of Malai and worthy sons of the soil, to help in the country's reconstruction." ${ }^{65}$ Beneath this nationalist rhetoric, however, the JMA resorted to more practical strategies of bolstering recruitment. Spokespersons like Shinozaki regularly reiterated that the volunteer units were given ranks, allowances and pay like that of Japanese soldiers. ${ }^{66}$ Shinozaki also tried to assure prospective enlistees that their religious customs would be respected. ${ }^{67}$ His labours in this regard suggest substantial resistance to the JMA's efforts to mobilize youth. The author of a Syonan Shinbum editorial on 9 January 1945 admitted the public had been misled by "idle and often malicious talk" about the Heiho and that "parents have also shown an indisposition to allow their sons to join up." ${ }^{68}$ These disciplinary projects were not foisted onto an agentic vacuum but onto populations that already possessed their own vested interests; they resisted Japanese attempts to mobilize their bodies in service of the new imperial master.

Accounts by interviewees who had been forcibly recruited into these units attested that volunteers were not really forthcoming and the Japanese authorities had to use "subterfuge and pressure" to recruit enlistees. ${ }^{69}$ According to Isa

62. Lebra, Japanese-Trained Armies in Southeast Asia, 116.

63. Syonan Shimbun, January 21, Koki 2604 Syowa 19 (1944).

64. Kratoska, The Japanese Occupation of Malaya and Singapore, 87.

65. Tan, Tik Loong Stanley. Syonan Years, 1942-1945: Living Beneath the Rising Sun (Singapore: The National Archives of Singapore, 2009), 75.

66. The Syonan Shimbun, July 1, Koki 2605 Syowa 20 (1945), 2.

67. Lebra, Japanese-Trained Armies in Southeast Asia, 117.

68. The Syonan Shimbun, January 9, Koki 2605 Syowa 20 (1945), 1.

69. Lee Geok Boi, Syonan: Singapore Under the Japanese, 1942-1945 (Singapore: 
Ibrahim, a Malay youth the Japanese authorities tried to recruit into the Giyugun during the war, the former encouraged Malay youth who were good at learning Japanese and who were already sportsmen to join the Giyu-gun or the Giyu-tai. He and his friends got out of the unit by lying that they had tuberculosis or week knees. ${ }^{70}$ At the same time, other oral history accounts suggest that the Heiho was able to recruit more volunteers than the other two units, probably because service with the Giyu-gun and Giyu-tai entailed a harsher life at the frontline than the Heiho, which took up local sentry and patrol roles. Witnesses and volunteers who joined the Heiho attested that the Heiho was made up of a substantial number of young Chinese men, and good number of Malay, Indians, and Eurasians, usually between the ages of eighteen and twenty-five. Many of these joined because of the pay and rations, and because Heiho members had the "privilege to move around." 71 A Malay enlistee Alias bin Osman even testified that the Japanese military motivated the enlistees through promises of Japanese girls as wives after the war. ${ }^{72}$

Despite the JMA's rhetoric about creating a united and disciplined population loyal to Japan out of Singapore's diverse communities, their efforts at youth mobilization were ultimately racialized. They employed "divide and rule" strategies, which sought to play one ethnic community against another to keep them in check. They also treated the different major ethnic communities in Singapore and Malaya differently, due to differing beliefs about each group's political loyalties and reliability. They considered the Indians that joined the Indian Independence Army and the Malays as pro-Japanese and regarded the Chinese and Eurasians with great suspicion and hostility. ${ }^{73}$

Accordingly, the JMA treated the youth of these communities differently. As Isa Ibrahim's above-mentioned account suggests, the Japanese mainly targeted Malay youth for recruitment into the para-military units. This was a continuation of Japanese policy in Malaya where they actively courted the support of the Malays and tried to channel Malay nationalism against their enemies. This resulted in Malay youth being more ready to join Japanese mobilization programmes than youth from other ethnic communities. Eric Paglar, an Eurasian youth who was trained to be a military interpreter for the

\section{Singapore Heritage Society: Landmark Books, 2017), 145.}

70. National Archives of Singapore (NAS), Oral History Centre, Isa Ibrahim, "The Public Service," Accession Number 000242, Reel 16.

71. NAS, Ng Jack Kim Boon, "Japanese Occupation of Singapore," Accession Number 000362, Reel 7; NAS, Soh Guan Bee, "Japanese Occupation of Singapore," Accession Number 000310, Reel 6; NAS, Lee Kip Lin, "Japanese Occupation of Singapore," Accession Number 000016, Reel 7.

72. NAS, Alias bin Osman, "Japanese Occupation of Singapore," Accession Number 000498, Reel 3.

73. Tan, Syonan Years, 1942-1945: Living Beneath the Rising Sun, 44-47. 
Japanese, attested that there were only one or two Chinese in the Giyu-gun and Giyu-tai and the rest were mostly Malays. ${ }^{74}$ The JMA encouraged Malay nationalism throughout the war and gave many Malay youth opportunities to receive military education and training in the above-mentioned paramilitary units. Many Malay-Muslim leaders, intellectuals, and young radicals cooperated with the Japanese for a few of reasons, including fear, a sense of patriotism, and the misplaced belief that the Japanese would help the Malays achieve Malayan independence within a larger Indonesia Raya. ${ }^{75}$ This was notwithstanding the significant number of Malays who were loyal to the British empire and took part in the fight against the Japanese.

For Indians, the JMA encouraged nationalist activity directed at winning independence for India from British rule. Singapore became a base for the Japanese to stir up the nationalist sentiments of Indian youths in India and Southeast Asia. They did not, however, recruit Indians into the Giyu-gun or Giyu-tai. Instead, they supported the formation of the Indian National Army and the Indian Independence League soon after the fall of Singapore as the primary organizations for Indian males. Indian women and girls were recruited into the Rani of Jhansi Regiment. The officers of first Indian National Army became suspicious of Japanese intentions, however, and resisted the latter's attempts to use the INA to invade other locations like New Guinea. This led to the arrest and detention of key INA officers and the dissolution of this first INA in late 1942. The INA and the Indian nationalist movement in Singapore were revived subsequently when another Indian nationalist Subhas Chandra Bose arrived in Singapore in July 1943 to re-organize these. ${ }^{76}$ In April 1944, the Japanese opened the Azad School, a training institute for Indian youth volunteers, at Gilstead Road in Singapore, and supported the formation of an Indian Youth Section of the Indian Independence League for Indian youth between the ages of 12 and $17 .{ }^{77}$ Throughout the rest of Occupation, they encouraged Indian youths to hold large rallies and recruitment drives for the anticolonial effort in India. Hence, Indian nationalist youth mobilization increased during the Japanese Occupation. However, this interest in encouraging Indian nationalism among Indian youth clearly undercut the efforts of other military educators and officers in instilling a new loyalty towards Japan.

74. NAS, Eric Charles Pemberton Paglar, "Japanese Occupation of Singapore," Accession Number 000299, Reel 9.

75. Abu Talib Ahmad, "The Impact of the Japanese Occupation on the Malay-Muslim Population," in Malaya and Singapore during the Japanese Occupation, ed. Paul Kratoska (Singapore: National University of Singapore, 1995), 17.

76. Lee, Syonan: Singapore Under the Japanese, 1942-1945, 97-99.

77. The Syonan Times, April 10, Koki 2604 Syowa 19 (1944); The Syonan Shimbun, August 30, Koki 2604 Syowa 19 (1944), 4. 
Conversely, the Occupation was especially traumatic for the Chinese who made up three-quarters of Singapore's population. The Japanese military authorities remained hostile to the Chinese. This was even as Shinozaki believed that it was necessary to acquire their support for Japan's imperial rule through a softer approach. The demographic significance of the Chinese in Singapore posed one of the greatest challenges to Japanese imperial rule, especially when they were already heavily politicized against the invaders before the Occupation. In Christopher Bayly and Tim Harper's words, General Yamashita "faced a sullen, hostile population," and was convinced that the "entire Chinese population of Singapore was a security threat to the Japanese Empire." ${ }^{178}$ More recently, Gregg Huff also underlined that one of the formidable difficulties the Japanese faced in managing Singapore was "its predominantly Chinese population and overwhelmingly Chinese character." 79

The Japanese military's hostility towards the Chinese community was largely due to the latter's hefty contributions to the defense of China against Japanese aggression across the 1930s and 1940s. Following the Japanese military's aggressive actions in China in the 1920s and 1930s, the overseas Chinese in Singapore and Malaya actively participated in fund-raising for the defence efforts in China and in anti-war or anti-Japanese activities. Notably, they formed a large-scale Overseas Chinese National Salvation Movement to coordinate fund-raising and volunteer recruitment efforts for anti-Japanese resistance after the Marco Polo Bridge incident in China in 1937. Within a year, the half a million Chinese in Singapore raised $\$ 5.7$ million Chinese dollars, the largest amount of funds raised among the different overseas Chinese communities in Southeast Asia. ${ }^{80}$

As the many studies and accounts of the Chinese community in Singapore's experience of the Second World War consulted for this article shown, many Chinese school-going children and young men, whether they were ideologically or politically aligned with the British empire, the Kuomintang, or the Malayan Communist Party, were active in the anti-Japanese resistance before and during the Japanese invasion. Boys and girls in the Chinese secondary school made and sold flowers and "Anti-Japan cookies and cakes" to raise funds to support the anti-Japanese resistance efforts in China; schoolgirls also sew winter clothing for frontline soldiers and refugees. ${ }^{81}$ The

78. Bayly and Harper, Forgotten Armies, 210.

79. Huff and Shinobu Majima, World War II Singapore: The Chōsabu Reports on Syonan, 3.

80. Koh, Ernest. Diaspora at War: The Chinese of Singapore Between Empire and Nation, 1937-1945. Leiden: Brill, c2013, 65.

81. Foong Choon Hon (ed.), The Price of Peace: True Accounts of the Japanese Occupation. Translated by Clara Show (Singapore: Asiapac Books, c1997), 226-229; Hsu Yun Tsiao \& Chua Ser Koon eds., Malayan Chinese Resistance to Japan 1937- 
editors of a seminal compilation of source materials belonging to Colonel Chuang Hui Tsuan, Deputy Regional Chief of Force 136, commentaries, and personal collections, added that Chinese youth were encouraged to go back to China to bear arms, to be drivers or medics to support the anti-Japanese resistance. ${ }^{82}$ When the Japanese $25^{\text {th }}$ Imperial Army invaded Malaya, young Chinese men in their twenties or younger readily responded to calls to help defend the island. Many joined the Overseas Chinese Volunteer army or other local defence units such as Dalforce. ${ }^{83}$ Even after the fall of Singapore, many young Chinese "entered the jungles and risked their lives to take up arms against the enemy." 84 Japanese brutality towards the Chinese community only drove more Chinese youth into a variety of covert anti-Japanese movements organized by the British, the Communists, and the Chinese Kuomintang, such as the Malayan People's Anti-Japanese Army and Force 136. The existence of these resistance movements increased the Japanese administration's anxieties about the loyalty of the Chinese youth.

Hence, the Japanese efforts to engineer new "Dai Toa" youth out of Singapore's children and youth had to contend with the reality that a substantial majority of these were not blank slates but politicized subjects, who already possessed a strong sense of antipathy towards Japan and were not easily receptive to Japanese propaganda or disciplinary efforts. In all, the Japanese military administration's different approaches to different groups of youth in Singapore, necessitated by broader Japanese strategic goals and by practical realities on the ground, fuelled ethnic-based nationalism among Malay, Chinese and Indian youth. This situation of divided loyalties undermined Japanese efforts to discipline local youth and their rhetoric and images of united "Syonan" or "Dai Toa" youth. It was impossible to instill a new consciousness and identity oriented towards Japan, the Japanese Emperor, or an unfamiliar concept of "Dai Toa," when the Japanese administration was also promoting nationalist sentiments among the Indian and Malay youth on the one hand, and alienating and persecuting Chinese and Eurasian youth on the other.

1945 - Selected Source Materials. Singapore: Cultural \& Historical Publishing House Pte. Ltd., 1984 许云樵 \& 蔡史君（编）。新马华人抗日史料, 1937-1947. 新加 坡：文史出版私人公司, 1984, 4

82. Hsu \& Chua, Malayan Chinese Resistance to Japan 1937-1945 - Selected Source Materials. Singapore: Cultural \& Historical Publishing House Pte. Ltd., 1984 许云 樵 \& 蔡史君 (编)。新马华人抗日史料, 1937-1947. 新加坡：文史出版私人 公司, 1984, p. 5

83. Foong Choon Hon (ed.). The Price of Peace: True Accounts of the Japanese Occupation. Translated by Clara Show (Singapore: Asiapac Books, c1997), 56.

84. Foong Choon Hon (ed.). The Price of Peace: True Accounts of the Japanese Occupation. Translated by Clara Show (Singapore: Asiapac Books, c1997), 60-61. 


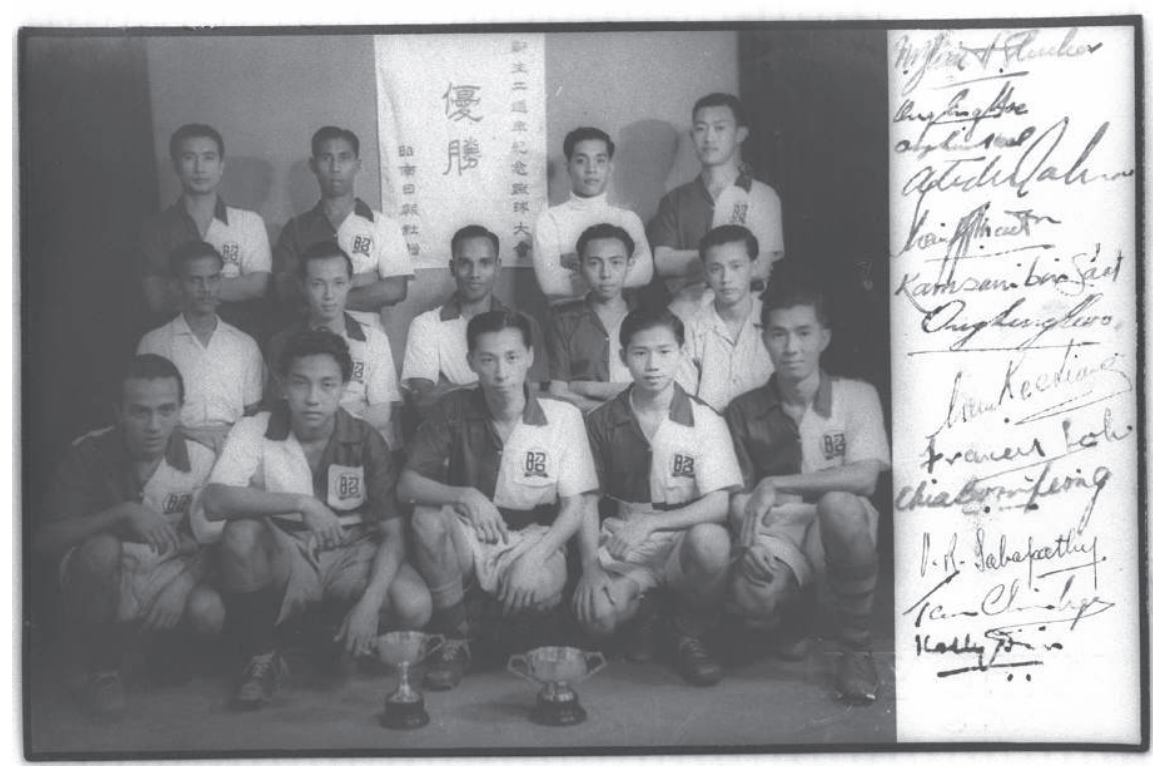

Fig. 2 - "The Syonan Sports Association- players from different soccer league teams to form the Singapore team", 1942-1945, image no. 19980005027 - 0080, negative no.NA12/30, with permission of National Archives of Singapore.

\section{The Valorization of the Young Male Body}

The needs of the wartime economy soon caused the JMA to mobilize both local young men and women in gendered ways that privileged male bodies over female ones. Japanese propaganda and recruitment practices valorized the disciplined, physically fit, youthful male body. Japanese military commanders in charge of youth training conceived of themselves as fathers cultivating a disciplined masculinity. In the words of Iwaki, a former educator and agricultural expert turned training commander of a Heiho camp, it was his "sincere desire" to see his trainees "return to their respective kampungs as new men with an outlook upon life completely new, and fully qualified to be the leaders of future Malaya." ${ }^{85}$ The Syonan Shinbum regularly highlighted interviews with local recruits of the Giyu-gun, the Giyu-tai, and the Heiho, and their parents. The latter lavished effusive praise on how the young recruits developed their physique, character, and abilities through military training. One letter-writer encouraged parents to send their sons to join the Heiho so that they would "grow up into men in every sense of the word - real he-men, healthy in body and sound in mind; proud and independent yet dependable and considerate, loyal and trustworthy

85. The Syonan Shimbun, January 8, Koki 2604 Syowa 19 (1944), 2. 
masters of their households and faithful citizens of a country." ${ }^{86}$ Another letterwriter repeated the trope of "boys becoming men" through military service. English education had turned his two boys into "absolute "wasters" but their enlistment in the Heiho turned them into "men." Japanese propagandists frequently employed this image of desirable maturity and discipline to coax the public to support their children's enlistment in military service. In March 1945, a press party purportedly visited the Giyu-tai's training camp. They waxed lyrical about finding hundreds of "sturdy, bronzed young men with an upright bearing and that disciplined smartness born of constant military training." 88 The welltrained, well-disciplined bodies of local male youth became embodied indexes of the new "Dai Toa" modernity and of the superiority of Japanese methods of disciplining youth.

From late 1943 onwards, male bodies became more than just symbols of Japanese cultural superiority. The turning of the war's momentum forced the JMA to compel Singapore residents to change their occupations and contribute their labour to the war effort. Two Japanese researchers who studied the labour situation in Japanese-managed factories and in the Syonan-to municipality emphasized the great shortage of labour and the need for direct and indirect countermeasures. These countermeasures included training and improving labour sources "by encouraging young people and women to work," by encouraging male workers to leave "inessential occupations" for essential ones and replacing them with females, older workers, and children. The report, in fact, highlighted the attitudinal shift in the minds of employers that was required to address the troubling labour shortages in the city: "businesses must abandon the view that females cannot be employed, and actively consider how to mobilize the female labour force." $" 89$

Accordingly, Shinozaki began to appeal to young men between sixteen and thirty-five to "undertake more responsible and essential work to be worthy citizens." This meant working in jobs that served Japanese military and industrial needs, volunteering for local defence, or taking up agricultural work to produce more food. ${ }^{90}$ In December 1944, the JMA introduced regulations requiring men between the ages of 15 and 40 to abandon jobs "not having any bearing towards the war effort" such as clerks, porters, hawkers, salesmen, telephone operators, lift operators, bellboys, ushers, and sweepers..$^{91}$ The

86. The Syonan Shimbun, January 10, Koki 2605 Syowa 20 (1945), 2.

87. The Syonan Shimbun, January 29, Koki 2605 Syowa 20 (1945), 2.

88. The Syonan Shimbun, March 6, Koki 2605 Syowa 20 (1945), 2.

89. Huff and Shinobu Majima, World War II Singapore: The Chōsabu Reports on Syonan, 294-295.

90. The Syonan Shimbun, January 7, Koki 2604 Syowa 19 (1944), 1.

91. Kratoska, The Japanese Occupation of Malaya and Singapore, 1941-45, 193. 
next month, the JMA passed a Male Employment Restriction Ordinance that prohibited any local man between these ages from working in occupations deemed "light and easy." Only youth with a "deformity" or "disability" were exempted from this requirement.

The JMA's labour needs converged with Japanese beliefs about labour as a powerful pedagogical technique for disciplining youth bodies. The effort to train bodies served the goal of extracting productive service from these bodies. Japanese propaganda focused on getting male children and youth to participate in labour service to toughen their bodies for their future civic responsibilities. In December 1943, the JMA began encouraging community organizations to create special labour units to meet the demand for labour. In response, the Malai Welfare Association (Malay Welfare Association) established a Free Labour Service Corps (Kinro Hoshi Dan) in January 1945 to rally Malay youth to spend their weekends in voluntary labour work. ${ }^{92}$ Various Islamic religious instruction centres in Singapore also formed the Syonan Muslim Students' Welfare Service Volunteer Corps to mobilize boys studying with them to render volunteer service to the country during their after-school hours. ${ }^{93}$ Altogether these efforts valorized male youth bodies as a source of vital labour, which needed to be extracted and developed for Japan's benefit. They also elevated voluntary labour as a vital act to both discipline the body as well as to demonstrate the individual's participation in the support of the community and the state.

The sacralization of young male bodies bore mixed implications for the place of local young women within Japanese propaganda and policies. Japan highlighted increasing educational and employment opportunities for girls as evidence of the social progress locals enjoyed under Japanese rule. Like its educational policies, the Japanese imperial administration's policies towards women in Singapore were based on changing gender norms and ideas from the imperial metropole. In April 1943, the Syonan Shinbum highlighted a special course on "domestic science and mothercraft" started at the Victoria Street Girls' School organized for seventy senior girls from all the public girls' school in the city. The subjects the students were taught Nippon-Go (Japanese), cooking, needlework, and art, housework, nursing, singing, physical training, arithmetic, hygiene, nature study, general and domestic science. Local Catholic nuns started a similar class at the Ceylon Road Girls' School. The Syonan Shinbum lauded the course as a course that prepared Singapore school girls for "their future responsibilities as mothers and wives... in a strong and virile New Malai." ${ }^{94}$ The new Malaya and Singapore was clearly one defined in

92. The Syonan Shimbun, February 1, Koki 2604 Syowa 19 (1944), 2.

93. The Syonan Shimbun, February 3, Koki 2604 Syowa 19 (1944), 2; The Syonan Shimbun, March 28, Koki 2604 Syowa 19 (1944).

94. The Syonan Shimbun, 2 April, Koki 2603 Syowa 18 (1943). 
masculine tropes of physical prowess and manly vitality, which subordinated girls as auxiliary to men in the new envisioned Dai Toa modernity. ${ }^{95}$ This constructed ideal of Japanese women, restricting them to the roles of familial caretakers and dutiful partners, can be traced back to the Meiji era during the turn of the $20^{\text {th }}$ century, when the modernizing Japanese state endeavoured to prepare girls and women to become "good wives and wise mothers" to advance the Japanese nation's strength, prosperity, and moral well-being. ${ }^{96}$ It was only after the First World War that Japanese officials, inspired by the examples of European and American women's groups that assisted the European and American forces in the war at the home front, that they began to promote the patriotic public roles of women during war beyond the confines of the "good wife and wise mother" paradigm..$^{97}$ The changing norms and ideas in Japan could have themselves been influenced by Western gendered ideas of education since English schools and British youth movements for girls like the Girl Guides also emphasized the above-mentioned subjects in the schooling of ideal girls. ${ }^{98}$ What remains important to highlight is how Japanese propaganda also valorized these images of ideal girls and women as part of the new modernity that Japan was bringing to the Asian countries it liberated.

In the early years of the Occupation, the Syonan Shimbun occasionally featured articles praising the examples of young Chinese girls who took up employment as petrol pump attendants, or as telephone operators for the military administration..$^{99}$ Beyond these examples, there did not appear to be much concerted effort to encourage girls or young women then. However, prolonged labour shortages forced the Japanese to pay greater attention to female labour. In 1944, they began to call on women to take over jobs vacated by males, but in a manner that subordinated the value of female labour to male labour. In February, the Japanese set up the Syonan Women's Employment Bureau to help find employment for female workers in Singapore. The organization found positions for a small number of women and girls and reported about 83 clerks, typists, nurses, and telephone operators, 19 waitresses, 228 amahs and domestic servants, 243 factory workers registered with the bureau. ${ }^{100}$ These small numbers suggested that Japanese efforts achieved only symbolic impact. The Japanese administration did not advance equality for women,

95. The Syonan Shimbun, April 2, Koki 2603, Syowa 18 (1943), 1.

96. Sheldon Garon, Molding Japanese Minds: The State in Everyday Life (Princeton, New Jersey: Princeton University Press, 1997), 115.

97. Ibid. 126.

98. My thanks to one anonymous reviewer of this paper for reminding me of this connection.

99. The Syonan Times, August 2, Syowa 17 (1942), 4; The Syonan Shimbun, January 19, Syowa 18 (1943), 2.

100. The Syonan Shimbun, May 30, Koki 2604 Syowa 19 (1944), 2. 
even as it envisioned a new public role for girls. Instead, Shinozaki and the JMA focused on young male bodies on the basis that these were needed for essential wartime labour, while other forms of work were deemed non-essential and to be left to females or older adults. ${ }^{101}$ A Japanese official, in explaining Japanese educational policies in 1943, avowed that the increased provision of technical education in the various trade and technical schools in Syonan for boys was meant to give them more opportunities to find employment as skilled mechanics and artisans to earn good salaries as Singapore's industries developed. Conversely, the official said, "their sisters could fill their places in offices where the work was not so strenuous."102 Throughout 1944 and 1945, Shinozaki and his colleagues appealed to various welfare associations established by the different ethnic communities to rally their women to volunteer for work on the home front. ${ }^{103}$ These appeals continued to reproduce essentialized images of women as mothers and housewives, but also began to call on them to play greater roles as nurses or in the auxilliary services. ${ }^{104}$ Yet, the premise remained that "their object should be to relieve men where possible so that the men may engage in essential tasks of a more important nature." 105 In October 1944, the JMA closed all cabarets and dance halls on the island and encouraged the female cabaret employees and "glamour girls" to register themselves for work to free men for more important work. In mid-1945, the Syonan Shimbun also reported the formation of a women's arm of the Auxiliary Police, the Joshi Tai (Women's Corps), and a Special Forward Service Corps to mobilize mostly Chinese young women and girls to assist in passive defence efforts by rendering humanitarian services, taking care of children, administering first aid, and fire-fighting. ${ }^{106}$ The belatedness of this wartime mobilization, as the Japanese occupation government became desperate for manpower, again underlines that the Japanese colonial disciplinary state was primarily focused on incorporating men into the state.

Even as Japanese administrators imposed a new paternity on young female bodies, they had to contend with older paternities that prevailed despite the JMA's efforts. Shinozaki was soon forced to publicly qualify the JMA's exhortation to women to come out to work. After announcing the Male Employment Restriction Ordinance, he issued a public clarification in the Syonan Shimbun that the legislation only applied to young men. He emphasized, in block letters, that

101. The Syonan Shimbun, January 10, Koki 2605 Syowa 20 (1945), 2; The Syonan Shimbun, January 13, Koki 2605 Syowa 20 (1945), 2.

102. The Syonan Shimbun, April 2, Koki 2603 Syowa 18 (1943).

103. The Syonan Shimbun, July 28, Koki 2604 Syowa 19 (1944), 1.

104. Ibid.

105. Ibid.

106. Syonan Shimbun Fortnightly 1, no. 5 (August 5), Koki 2605 Syowa 20 (1945), $5 \& 14$. 


\begin{abstract}
"THE AUTHORITIES WISH IT TO BE CLEARLY UNDERSTOOD, HOWEVER, THAT THEY ARE NOT COMPELLING WOMEN TO WORK, OR PUTTING INTO EFFECT ANY ORDINANCE FOR MOBILIZATION OF FEMALE LABOUR POWER. THE AUTHORITIES RESPECT THE MANY RELIGIOUS AND RACIAL CUSTOMS PREVAILING IN THIS CITY AND WILL NOT COMPEL WOMEN TO WORK UNLESS THEY VOLUNTARILY WISH TO DO SO."107
\end{abstract}

Evidently, the JMA's efforts to rally women to join the labour force met with fierce opposition from the conservative social groups in Singapore, which could not be alienated at a crucial moment in the war effort. Disciplinary projects are easier conceived than achieved in the face of existing subjectivities that resist these attempts to assert power over bodies.

Nonetheless, Japanese propagandists and officials also deployed the bodies of young women as embodied metaphors of the "Dai Toa" ideal. In this case, they did not only instrumentalize their femininity and youthfulness, but also racialized their bodies to paint a mythical image of multicultural unity under Japanese hegemony. The "Daughters of Dai Toa" first appeared as a feature series of interviews during the anniversary week of Singapore's surrender. Each day, the Syonan Shinbum featured an interview with a different "Daughter of Dai Toa," i.e., a young woman representing each major ethnic community in Singapore and Malaya. In these interviews, each "Daughter of Dai Toa" expressed reverence for Japan, affirmed their adherence to the imperial cause, and presented themselves as role models of female "Dai Toa" youth. The first "Daughter of Dai Toa" featured was Rene Paglar, the 14-year-old daughter of Dr. C.J. Paglar, a leader of the Eurasian community in Singapore. The article depicted her as a bright and civic-minded girl who spoke five languages and who, as a member of the Medical Auxiliary Services, helped her father as a nurse after her day's studies. Her love for learning the Japanese language and her sense of selfless duty, the article exclaimed, meant that she was behaving in every way a "Nippon-Fujin" (i.e., a mature Japanese woman). Rene Paglar "looked a typical maiden of Dai Toa" in her "striking purple kimono, complete with a red obe and clogs." Again, beneath the grand rhetoric of pan-Asian autonomy and independence, the Japanese concept of "Dai Toa" was based on local veneration and embrace of Japanese culture. ${ }^{108}$ Paglar, the article claimed, longed to travel to Japan to see the flowers of Japan and further her studies there. After Rene Paglar, the "Daughters of Dai Toa" included young women representing the other ethnic communities in Singapore: Sheum Yu Kwei, a Chinese saw-dust artiste; Patricia Piol, a Singapore-born Filipino student of the Victoria Street Girls' School, 15 year-old Sima Binte Noorlim, and lastly, Janaki Davar, a platoon commander in the Rani of Jhansi Regiment of the Indian

107. The Syonan Shimbun, February 12, Koki 2605 Syowa 20 (1945), 2.

108. The Syonan Shimbun, February 11, Koki 2604 Syowa 19 (1944), 2. 
National Army. ${ }^{109}$ The last clearly had words put in her mouth where she called on all "Asiatics" to create co-prosperity and develop "Dai Toa-mindedness" this was an unlikely position as a nationalist oriented towards India.

The "Daughters of Dai Toa" subsequently appeared in "comfort shows" in other settings and occasions, such as for patients in military hospitals and members of the Giyu-gun in late April 1944 to commemorate the Japanese Emperor's birthday. ${ }^{110}$ This time, the "Dai Toa Revue Party" had expanded to include representatives from all of Japan's occupied territories - Miss Philippines, Miss India, Miss Manshukoku (Manchuria), Miss Malai (Malaya), Miss Thailand, Miss Burma, and Miss China. Rene Paglar was identified not by a geographical location but as "Miss Aojin" (European). The JMA's agenda once again was to use the bodies of eight young women from different cultural backgrounds to stage the Japanese's "Dai Toa" ideal. In his oral history account, Eric Paglar, the brother of Rene Paglar, speculated that the purposes of this "cultural troupe" were to show that the populace "appreciated the Japanese's liberation" and to boost the morale of wounded Japanese troops. ${ }^{111}$ There was no "Miss Japan" joining these other young women on the stage. ${ }^{112}$ Only Japan's new colonies, and not the metropole itself, could be femininized and objectified for the gaze of the foot-soldiers of Japanese imperialism in Southeast Asia.

\section{The End of a Beginning}

Japan surrendered on 15 August 1945. In the end, this is more a story of what might have been, of unfulfilled Japanese fantasies about the moulding and mobilization of youth in Singapore. The Japanese Occupation delivered little of the promised "co-prosperity" in Singapore. The scholars who had studied the Japanese failure to win hearts and minds and Nipponize the population agreed on the few explanations. ${ }^{113}$ Severe food shortages resulted in malnutrition, which exacerbated the spread of diseases. For all Japanese claims about the benefits of Japanese hegemony for children and youth, the inability to ensure adequate food supplies and agricultural production meant that "between about two-fifths and two-thirds of Singapore school children

109. The Syonan Shimbun, February 12, Koki 2604 Syowa 19 (1944), 2; The Syonan Shimbun, February 14, Koki 2604 Syowa 19 (1944), 2; The Syonan Shimbun, February 16, Koki 2604 Syowa 19 (1944), 2.

110. The Syonan Shimbun, April 26, K2604, Syowa 19 (1944), p. 2

111. NAS, Eric Charles Pemberton Paglar, "Japanese Occupation of Singapore," Accession Number 000299, Reel 43.

112. The Syonan Shimbun, April 22, Koki 2604 Syowa 19 (1944); The Syonan Shimbun, April 26, Koki 2604 Syowa 19 (1944).

113. Huff, World War II and Southeast Asia: Economy and Society under Japanese Occupation, 70. 
were malnourished by pre-war standards. ${ }^{114}$ This was notwithstanding Japanese brutalities and racism towards the locals. Even though Japanese propaganda attempted to paint a rosy picture of social progress for women, the reality was that most girls and women experienced deprivation, starvation, trauma, and ill-fortune. The epitome of this reality, as Geoff Huff outlined, were the many women conscripted as 'comfort women' for Japanese troops, the female children who were sold into prostitution, and the many girls who had to be treated for venereal disease in $1946 .{ }^{115}$

The scholars who have studied Japanese social and economic policies have agreed that the efforts to "Nipponize" youths were far too impracticable given the wartime situation and the realities in Singapore. Eri Hotta points out that the task of administering the Greater East Asia Co-Prosperity Sphere "quickly proved a task far beyond Japan's capacity." 116 The historical records show that the JMA was more focused on immediate short-term war aims the consolidation of political control, the revival of the economy, and the expansion of industry to feed Japan's military and industrial needs. By the end of 1943, the Japanese war machine was struggling to repel the Allied counterinvasion, especially after the United States entered the war following the bombing of Pearl Harbor. As the tide of war turned against them, the exigency of mobilizing the young for the Japanese war engine and economy overrode all other cultural or social plans or policies.

The shortcomings in the implementation of the policies stymied the efforts to create a new consciousness and identity as youth united under Japanese rule. Paul Kratoska has made a damning assessment: "The educational and propaganda undertakings of the Japanese seem both audacious and naïve: audacious in the scope of the changes they hoped to achieve, and naïve in underestimating the tenacity with which the people of Malaya would cling to their values and way of life." 117 The Nipponization program was easier to conceive than to materialize. The need to retain the support of the Malays and Indians made it impossible for Japanese administrators to be too forceful in imposing Japanese culture. Many Chinese parents were reluctant to send their children to school, in part because of their animosity towards the Japanese. According to Turnbull, never more than 7,000 children were in school and by 1945, the number "had dwindled to a few hundred." 118 Circumstances like the need to return dislocated youth to school forced the JMA to allow Shinozaki to

114. Huff and Huff, "The Second World War Japanese Occupation of Singapore," 265.

115. Huff, World War II and Southeast Asia: Economy and Society under Japanese Occupation, 390-391.

116. Hotta, Pan-Asianism and Japan's War, 199.

117. Kratoska, The Japanese Occupation of Malaya and Singapore, 125.

118. Turnbull, A History of Modern Singapore, 210. 
re-open existing schools, including the Chinese-medium schools and Englishmedium schools. From April 1942, vernacular primary schools re-opened. Shinozaki also allowed the teaching of English in English-medium schools, annoying the anti-Western military officers like Wataru, due to the shortage of Japanese teachers and Japanese textbooks to teach Japanese. ${ }^{119}$ Hence, for all of Shinozaki and the Japanese military officers' desires to create a new consciousness through schooling local children and youth, wartime exigencies caused the re-emergence of the pre-war system of vernacular schools and the amplification of ethnic consciousness among the local communities. ${ }^{120}$ Clearly, disciplinary intent did not guarantee disciplinary outcomes or effects, especially if would-be subjects evaded and avoided these disciplinary institutions and programs altogether due to a lack of interest and investment, or worse, adopted an attitude of resistance.

Yet, the Japanese's application of biopolitical power was productive. Even though the outcomes fell short of the Japanese officers and officials' intentions, their efforts stimulated the nascent nationalist movements in Singapore and gave many young people the chance to receive education, leadership training, and military training. Some testified after the war that participation in Japanese training programs gave them qualities, such as physical and mental discipline, that enabled them to function as leaders. ${ }^{121}$ In the words of Haji Rahmat bin Kenap, a teenager who joined the Heiho, "they taught us how to fight, and later on, how to farm." 122 Another Malay individual who joined the Heiho attested that he felt treated like trusted equals by the Japanese army, and as "the little brothers, their right hand man." ${ }^{123}$ Scholar Abu Talib Ahmad reminds us that the Occupation had some positive aspects for the Malays in Malaya and Singapore - it germinated new political awareness among Malay youth, involved Malay women in political and social organizations and increased "the ability of the Malay people to break out of their parochial environment.".124 This heightened ethnic awareness and nationalistic pride infected post-World War Two political debates and struggles.

There was another significant legacy of the short-lived Japanese Occupation. Japanese policies and propaganda normalized the idea that the welfare, education, and development of the young was part of everyday social policy and

119. Shinozaki, Syonan-to: My Story, 34.

120. Wilson, "Educational Policy and Performance in Singapore, 1942-1945," 7.

121. Kratoska, The Japanese Occupation of Malaya and Singapore, 1941-45, 159.

122. Cited in Tan, Tik Loong Stanley. Syonan Years, 1942-1945: Living Beneath the Rising Sun. Singapore: The National Archives of Singapore, 2009, 76.

123. Alias bin Osman, "Japanese Occupation of Singapore," Accession Number 000498, Reel 10.

124. Abu Talib Ahmad, "The Impact of the Japanese Occupation on the MalayMuslim Population," 1. 
governance. Japanese administrators substantially increased the opportunities for education for local children and youth in their pursuit of their disciplinary and political goals. In 1943, the authorities announced that free education would be provided to all 17,000 school children attending the Syonan Tokubetu-si Futso Ko Gakko (common public schools). ${ }^{125}$ Japanese propaganda waxed lyrical about the "remarkable progress made in education in Syonan." ${ }^{126}$ This was even though wartime conditions and the hostility of the different communities towards the Japanese administration kept the numbers of students in school substantially lower than the level of enrolment in the schools in the colony before the war. As Hsu and Chua have shown, the number of Chinese, English, and Indians schools that were opened, and the number of pupils that attended school during the Syonan era, were substantially lower than the numbers before the war. ${ }^{127}$

Between 1942 and 1945, the Japanese also set up numerous sorts of technical schools to train Syonan youth as technicians, mechanics, electricians, engineers as part of their measures to mobilize labour and to increase labour productivity. For instance, the Koku Kogyo Gakki, an aviation and technical school, was opened in mid-1942 to train boys aged thirteen to twenty as technicians for military aircraft and equipment. These schools gave more local youth the opportunities to pursue vocational and technical education. Mohd Harris bin Abdul Karim was one of those who became an aircraft technician after receiving such training. He attested that the education the Japanese gave" was better than what we received in the trade schools during the pre-war years." 128

Opportunities for education and training went together with the provision of more opportunities for jobs and leadership training. For all their unrequited imperial fantasies about the moulding and mobilization of Syonan youth, the various programs Shinozaki, Wataru, and the JMA started had made it impossible for the returning colonial authorities to ignore the interests and welfare of the young once again - the provision of education, jobs, developmental opportunities became tied to the politics of youth representation and imperial legitimacy. Biopower, unleashed, produced its own momentum. As Geoff Huff writes, the "single unambiguous Japanese success in Southeast Asia was the destruction of Western colonialism" by removing colonial forces and promoting local nationalism and upending the colonial order irrevocably. ${ }^{129}$ One can add that, for the case of Singapore, Japanese rule accelerated the process by thrusting many young people into agentic roles. They acquired

125. The Syonan Shimbun, December 3, Koki 2603 Syowa 18 (1943), 2.

126. Tan, Syonan Years, 1942-1945: Living Beneath the Rising Sun, 107.

127. Hsu \& Chua, Malayan Chinese Resistance to Japan 1937-1945 - Selected Source Materials, 52.

128. Tan, Syonan Years, 1942-1945: Living Beneath the Rising Sun, 177.

129. Huff, World War II and Southeast Asia: Economy and Society under Japanese Occupation, 378. 
educational and leadership opportunities at an unprecedented level, setting the stage for the ascendancy of youth activism and mobilization after the war, shaping post-war developments.

\section{References}

\section{Primary Sources}

Syonan Times; Syonan Shimbun, Syowa 2602-2605 (1942-1945)

Oral History Recordings (National Archives of Singapore, Oral History Centre)

Isa Ibrahim, "The Public Service," Accession Number 000242, Reel 16.

Ng, Jack Kim Boon, “Japanese Occupation of Singapore,” Accession Number 000362, Reel 7.

Alias bin Osman, “Japanese Occupation of Singapore," Accession Number 000498, Reels 3 \& 10.

Eric Charles Pemberton Paglar, "Japanese Occupation of Singapore," Accession Number 000299, Reels 9 \& 43.

Soh Guan Bee, “Japanese Occupation of Singapore,” Accession Number 000310, Reel 6.

\section{Secondary Sources}

Abu Talib Ahmad, 1995. "The Impact of the Japanese Occupation on the Malay-Muslim Population." In Malaya and Singapore during the Japanese Occupation, edited by Paul Kratoska, 1-36. Singapore: National University of Singapore.

Akashi, Yoji, 1991. “Japanese Cultural Policy in Malaya and Singapore, 1942-1945." In Japanese Cultural Policies in Southeast Asia during World War 2, edited by Grant K. Goodman, 117-172. New York: St. Martin's Press.

Akashi, Yoji, 2008. "Colonel Watanabe Wataru: The Architect of the Malayan Military Administration, December 1941- March 1943." In New Perspectives on the Japanese Occupation in Malaya and Singapore, 1941-1945, edited by Yoji Akashi and Yoshimura Mako, 33-64. Singapore: National University of Singapore Press.

Ambaras, David R., 2006. Bad Youth: Juvenile Delinquency and the Politics of Everyday Life in Modern Japan. Berkeley: University of California Press.

Blackburn, Kevin and Karl Hack, 2012. War Memory and the Making of Modern Malaysia and Singapore. Singapore: NUS Press.

Bayly, Christopher and Tim Harper. Forgotten Armies: Britain's Asian Empire and the War with Japan. London: Penguin Books, 2005.

Blaxell, Vivian, 2008. "New Syonan and Asianism in Japanese-era Singapore." The Asia-Pacific Journal, Jan 1, 2008, Vol.6 Issue 1. Accessed at https://apjjf.org/-Vivian-Blaxell/2644/ article.html.

Chatani, Sayaka, 2018. Nation-empire: Ideology and Rural Youth Mobilization in Japan and Its Colonies. Ithaca: Cornell University Press.

Chew, Ernest C.T. and Edwin Lee (eds), 1991. A History of Singapore, Oxford: Oxford University Press.

Farrell, Brian P., c2005. The Defense and Fall of Singapore. Stroud: Tempus.

Foong Choon Hon (ed.), c1997. The Price of Peace: True Accounts of the Japanese Ocupation. Translated by Clara Show. Singapore: Asiapac Books.

Frühstück, Sabine, 2017. Playing War: Children and the Paradoxes of Modern Militarism in Japan. Oakland, California: University of California Press. 
Garon, Sheldon, 1997. Molding Japanese Minds: The State in Everyday Life. Princeton, New Jersey: Princeton University Press.

Goodman, Grant K (ed.), 1991. Japanese cultural policies in Southeast Asia during World War 2. New York: St. Martin's Press.

Hotta, Eri, 2007. Pan-Asianism and Japan's War, 1931-1945. New York: Palgrave Macmillan.

Hsu Yun Tsiao \& Chua Ser Koon eds., 1984. Malayan Chinese Resistance to Japan 1937-1945-Selected Source Materials. Singapore: Cultural \& Historical Publishing House Pte. Ltd., 许云樵 \& 蔡史君（编）。新马华人抗日史料, 1937-1947. 新加坡：文史 出版私人公司.

Gregg Huff and Gillian Huff, 2000. "The Second World War Japanese Occupation of Singapore." Journal of Southeast Asian Studies, 51, 1-2 (2020): 243-270.

Huff, Gregg and Shinobu Majima (eds), 2018. World War II Singapore: The Chōsabu Reports on Syonan. Singapore: NUS Press, National University of Singapore.

Huff, Gregg, 2020. World War II and Southeast Asia: Economy and Society under Japanese Occupation. Cambridge, UK; New York, NY: Cambridge University Press.

Koh, Ernest, c2013. Diaspora at War: The Chinese of Singapore Between Empire and Nation, 1937-1945. Leiden: Brill.

Kratoska, Paul, 2018. The Japanese Occupation of Malaya and Singapore, 1941-45: A Social and Economic History, $2^{\text {nd }}$ edition. Singapore: NUS Press.

Kwa Chong Guan \& Kua Bak Lim (eds.), 2019. A General History of the Chinese in Singapore. Singapore: Singapore Federation of Chinese Clan Associations: World Scientific.

Lebra, Joyce C., 1977. Japanese-Trained Armies in Southeast Asia: Independence and Volunteer Forces in World War II. New York: Columbia University Press.

Lee, Geok Boi, 2017. Syonan: Singapore Under the Japanese, 1942-1945. Singapore: Singapore Heritage Society: Landmark Books.

Leow, Rachel, 2014. "Age as a Category of Gender Analysis: Servant Girls, Modern Girls, and Gender in Southeast Asia." The Journal of Asian Studies 71, no. 4 (2014): 975-990.

Matsuoka, Masakazu, 2009. "Nihon gunsei ka Singaporu ni okeru kodomo muke ongaku kousaku (Japanese Propaganda through Music toward School Children during Japanese Occupation of Singapore)." Researches of Educational History in Asia 18 (March 2009): 48-64.

Matsuoka, Masakazu, 2012. “'Shonantou' ni okeru 'bunkajin': Kodomo muke shinbun kara no kousatsu ("Intellectuals" in Singapore under Japanese Occupation: A Consideration of Their Involvement in a Newspaper for School Children)." Annual Review of Historical Studies of Colonial Education 14 (2012): 141-159.

Matsuoka, Masakazu, 2013. "Nihon senryou ka singaporu ni okeru kodomo muke puropaganda no shishou teki kigen: Doushinshugi to nanpou muke nihongo kyoiku no renzokusei ni kansuru kousatsu (Comprehensive Study on the School Textbooks and New Education Movement in Japanese Colonies and Japanese-Occupied Areas).” Research Report of the JSPS Grant-inAid for Scientific Research (B) 22330207 (2010-2012), March 2013: 297 - 309.

Morris, Ivan 5ed.), 1963. Japan 1931-1945: Militarism, Fascism, Japanism? Lexington: D.C. Heath and Company.

Ooi, Ophelia, 1980. "Inquiry into the Political Activities of the Japanese in Singapore, 19301942." Unpublished academic exercise, Department of History, University of Singapore.

Pomfret, David M., 2008. "“Child Slavery' in French and British Far-Eastern Colonies, 18801945." Past and Present 201, no. 1 (2008): 175-213.

Pomfret, David M., 2009. “'Raising Eurasia': Race, Class and Age in Hong Kong and Indochina." Comparative Studies in Society and History 51, no. 2 (2009): 314-343. 
Shingaporu Nihonjinkai (The Japanese Association, Singapore), 1998. 戦前シンガポールの 日本人社会 : 写真と記錄 (Prewar Japanese community in Singapore: Picture and Record). Singapore: Shingaporu Nihonjinkai.

Shingaporu Nihonjinkai (The Japanese Association, Singapore), 2016. シンガポール日本人 社会百年史 ： 星月夜の耀 (100 Year History Of Japanese Community In Singapore $(1915 \sim 2015))$. Singapore: Shingaporu Nihonjinkai.

Shinozaki, Mamoru, 1973. My wartime experiences in Singapore. Interviewed by Lim Yoon Lin. Singapore: Institute of Southeast Asian Studies.

Shinozaki, Mamoru, 1975. Syonan - My Story: The Japanese Occupation of Singapore. Singapore: Asia Pacific Press.

Tan, Tik Loong Stanley, 2009. Syonan Years, 1942-1945: Living Beneath the Rising Sun. Singapore: The National Archives of Singapore.

Thio, Eunice, 1991. “The Syonan Years, 1942-1945." In A History of Singapore, eds. Ernest C.T. Chew and Edwin Lee, 95-114. Singapore: Oxford University Press.

Wilson, Harold E., 1978. Social Engineering in Singapore: Educational Policies and Social Change, 1819-1972. Singapore: Singapore University Press.

Wilson, Harold E., 1973. "Educational Policy and Performance in Singapore, 1942-1945." ISEAS Occasional Paper No. 16. Singapore: Institute for Southeast Asian Studies.

Wong, Lin Ken. "Commercial Growth Before the Second World War." In A History of Singapore, edited by Ernest C.T. Chew and Edwin Lee, 41-65. Oxford: Oxford University Press, 1991.

Wu, Jialin Christina, 2014. “A Life of Make-Believe: Being Boy Scouts and 'Playing Indian' in British Malaya (1910 - 1942).” Gender \& History 26, no. 3 (November 2014): 589 - 619.

Wu, Jialin Christina, 2015. "A Malayan Girlhood on Parade: Colonial Femininities, Transnational Mobilities and the Girl Guide Movement in British Malaya." In Transnational Histories of Youth in the Twentieth Century, edited by Richard Ivan Jobs and David M. Pomfret, 92-112. London: Palgrave Macmillan. 
